\title{
Perencanaan Sarana dan Prasarana Pendidikan di SMK Negeri 1 Percut Sei Tuan
}

\author{
Usiono ${ }^{1}$, Askur Amin ${ }^{2}$,Samsir Damanik*3 \\ ${ }^{1}$ (Universitas Islam Negeri Sumatera Utara Medan) \\ ${ }^{3}$ (Universitas Islam Negeri Sumatera Utara Medan) \\ ${ }^{2}$ (Universitas Islam Negeri Sumatera Utara Medan)
}

* Corresponding Author. E-mail: samsirdamanik45@gmail.com

\begin{tabular}{|l|l|l|}
\hline Receive: 13/05/2021 & Accepted: 23/08/2021 & Published: 01/10/2021
\end{tabular}

\begin{abstract}
Abstrak
Secara Umum, penelitian ini bertujuan untuk mendeskripsikan proses pengelolaan sarana dan prasarana pendidikan di SMK Negeri 1 Percut Sei Tuan, dalam konteks yang terfokus kepada perencanaan sarana dan prasarana pendidikan di SMK Negeri 1 Percut Sei Tuan. Penelitian ini menggunakan jenis penelitian kualitatif, dengan pendekatan deskriftif. Hasil penelitian mengungkapkan bahwa: Perencanaan sarana dan prasarana di SMK Negeri 1 Percut Sei Tuan merupakan tahapan awal dalam pengelolaan sarana dan prasarana di sekolah tersebut, di dalam perencanaan itu ada keseluruhan proses perkiraan secara matang rancangan kebutuhan fasilitas yang diperlukan oleh peserta didik, guru-guru dan seluruh staf yang ada di SMK Negeri 1 Percut Sei Tuan, termasuk rancangan pembelian, pengadaan rehabilitasi, distribusi serta pengadaan perlengkapan sekolah tersebut. Perencanaan sarana dan prasarana pendidikan di SMK Negeri 1 Percut Sei Tuandilakukan melalui tahapan sebagai berikut: (1) Menampung semua usulan pengadaan perlengkapan sekolah yang diajukan oleh setiap jurusan di SMK Negeri 1 Percut Sei Tuan. (2) Menyusun rencana kebutuhan perlengkapan sekolah untuk periode tertentu. (3) Melakukan analisis dan penentuan skala prioritas kebutuhan, (4) Memadukan rencana kebutuhan dengan dana atau anggaran sekolah yang tersedia. (5) Penetapan rencana pengadaan sarana dan prasarana.
\end{abstract}

\section{Kata Kunci: Perencanaan, Sarana Prasarana, Pendidikan}

\section{Abstract (English-Indonesia)}

In general, this study aims to describe the process of managing educational facilities and infrastructure at SMK Negeri 1 Percut Sei Tuan, in a context that focuses on planning educational facilities and infrastructure at SMK Negeri 1 Percut Sei Tuan. This study uses a qualitative research type, with a descriptive approach. The results of the study reveal that: Planning for facilities and infrastructure at SMK Negeri 1 Percut Sei Tuan is the initial stage in the management of facilities and infrastructure at the school, in that planning there is an entire process of carefully estimating the design of facility requirements needed by students, teachers and all staff at SMK Negeri 1 Percut Sei Tuan, including the purchase plan, procurement of rehabilitation, distribution and procurement of school equipment. Planning for educational facilities and infrastructure at SMK Negeri 1 Percut Sei Tuan is carried out through the following stages: (1) Accommodating all proposals for procurement of school equipment submitted by each department at SMK Negeri 1 Percut Sei Tuan. (2) Prepare a plan for school equipment needs for a certain period. (3) Conducting analysis and determining the priority scale of needs, (4) Integrating the needs plan with available school funds or budgets. (5) Determination of the plan for the procurement of facilities and infrastructure.

\section{Keywords: Planning, Infrastructure, Education}




\section{Pendahuluan}

Pendidikan adalah usaha sadar dan terencana untuk mewujudkan suasana belajar dan proses pembelajaran agar peserta didik secara aktif mengembangkan potensi dirinya untukmemiliki kekuatan spiritual keagamaan,pengendaliandiri, kepribadian, kecerdasan, akhlak mulia, serta keterampilan yang diperlukan dirinya, masyarakat, bangsa dan Negara. Oleh karena begitu pentingnya pendidikan ini sebagai tempat bagi para peserta didik untuk dapat mengembangkan minat dan bakatnya, maka tentunya untuk dapat mencapai tujuan dari pendidikan itu sendiri yaitu sebagai pembentuk karakter seseorang, maka memerlukan proses pembelajaran yang mempunyai kesingkronisasian dengan kebutuhan peserta didik dan umumnya masyarakat. (Minarti. Sri, 2016).

Sistem pendidikan nasional adalah keseluruhan komponen pendidikan yang saling terkait secara terpadu untuk mencapai tujuan pendidikan nasional. Berdasarkan pasal $3 \mathrm{UU}$ Sikdiknas No 20 tahun 2003 tentang pendidikan nasional bahwa pendidikan nasional berfungsi mengembangkan kemampuan dan membentuk watak serta peradaban bangsa yang bermartabat dalam rangka mencerdaskan kehidupan bangsa, bertujuan untuk mengembangkan potensi peserta didik agar menjadi manusia yang beriman dan bertaqwa kepada Tuhan Yang Maha Esa, berakhlak mulia, sehat, cakap, kreatif, mandiri, dan menjadi warga negara yang demokratis serta bertanggung jawab.

Dalam rangka meningkatkan kualitas pendidikan nasional, pemerintah telah melakukan berbagai upaya seperti yang juga dimuat dalam Undang-undang Nomor 20 Tahun 2003 tentang Sistem Pendidikan Nasional yang didalamnya mencakup dasar dan tujuan penyelenggaraan pendidikan termasuk wajib belajar, penjaminan kualitas pendidikan serta peran masyarakat dalam sistem pendidikan nasional. Kebijakan tersebut dibuat untuk menghasilkan Pendidikan Indonesia yang baik dan lulusan berkualitas di sektor jenjang pendidikan.

Untuk mendukung hal tersebut terlebih dahulu menentukan standar yang harus menjadi acuan pelaksanaan kegiatan pendidikan, maka untuk itu pemerintah mengeluarkan Peraturan Pemerintah Nomor 19 Tahun 2005 tentang standar nasional pendidikan. Adapun standar yang menjadi dasar bagi penyelenggaraan pendidikan sebagaimana yang diatur dalam pasal 17 Peraturan Pemerintah No 19 Tahun
2005 yaitu: (1) Standar Isi, (2) Standar Proses, (3) Standar Kompetensi Lulusan,Standar Pendidik dan Tenaga Kependidikan, (5) Standar Sarana dan Prasarana, (6) Standar Pengelolaan, (7) Standar Pembiayaan, (8) Standar Penilaian.

Proses pendidikan akan terganggu bila salah satu komponen tersebut tidak tersedia. Salah satu komponen tersebut adalah sarana dan prasarana. Keberadaan sarana dan prasarana pendidikan mutlak dibutuhkan dalam proses pendidikan, sehingga termasuk dalamkomponen-komponen yang harus dipenuhi. Tanpa sarana dan prasarana pendidikan, proses pendidikan akan mengalami kesulitan yang sangat serius, bahkan bisa menggagalkan pendidikan. Suatu kejadian yang mesti dihindari oleh semua pihak yang terlibat dalam pendidikan.(Direktorat Tenaga Kependidikan, 2007).

Sarana dan prasarana pendidikan memegang peranan yang sangat penting dalam usaha menciptakan suasana yang kondusif dunia pendidikan. Proses pendidikan tidak akan berjalan dengan baik tanpa didukung dengan adanya sarana dan prasarana yang baik pula. Agar tujuan pendidikan tersebut dapat dicapai maka perlu diperhatikan segala sesuatu yang mendukung keberhasilan tujuan pendidikan itu. Dari sekian faktor penunjang keberhasilan tujuan pendidikan, kesuksesan dalam proses pembelajaran merupakan salah satu faktor yang dominan. Sebab didalam proses pembelajaran itulah terjadinya interialisasi nilai-nilai dan pewarisan budaya maupun norma-norma secara langsung. Karena itu, kegiatan belajar mengajar merupakan ujung tombak untuk tercapainya pewarisan nilai-nilai diatas.(Rusydi Ananda, Oda Kinata Banurea, 2017).

Dengan demikian dalam memenuhi kebutuhan sarana dan prasarana pendidikan yang diperlukan perlu disusun perencanaan sebagai proses pemikiran dan penetapan program pengadaan fasilitas yang ada sehingga tujuan pendidikan dapat tercapai. Selain perencanaan yang baik, pelaksanaannya pun harus dikelola dengan baik pula, mulai dari pengadaan, pendistribusian, penggunaan, pemeliharaan, inventarusasi dan penghapusan, dilakukan pengawasan secara berkala. (Direktorat Tenaga Kependidikan, 2007).

Terkait dengan hal di atas, manajemen sarana dan prasarana mutlak harus diadakan dalam proses pendidikan. Manajemen sarana dan prasarana pendidikan bertugas mengatur dan menjaga sarana dan prasarana pendidikan agar dapat memberikan kontribusi secara 
Jurnal Edumaspul, 5 (2), Year 2021 - 125

(Usiono,Askur Amin,Samsir Damanik)

optimal dan berarti pada jalannya proses pembelajaran. Agar semua fasilitas dapat digunakan secara optimal dalam proses pembelajaran, maka fasilitas tersebut hendaknya dikelola dengan baik. (Malang, 2003)

Sarana dan prasarana sebagai salah satu bagian dari manajemen yang ada di lembaga pendidikan, sarana dan prasarana mempunyai peran yang sangat penting dalam suatu organisasi, institusi ataupun lembaga pendidikan. Dalam suatu lembaga pendidikan tentu memiliki cara tersendiri dalam mengelola sarana dan prasarana pendidikannya. Kepala sekolah bertanggung jawab terhadap pemenuhan sarana dan prasarana pendidikan di lembaga sekolah yang dikelolanya dengan dibantu oleh wakil kepala sekolah dibidang sarana dan prasarana.(Rusydi Ananda, Oda Kinata Banurea, 2017).

Untuk mewujudkan pusat sumber belajar yang baik dan ideal, suatu lembaga pendidikan mau tidak mau wajib menyediakan sarana prasarana pendidikan yang lengkap dengan kondisi yang baik sesuai dengan kurikulum pelajaran yang ada.

Kepala sekolah dalam mengelola sarana dan prasarana sekolah harus menyusun rencana sesuai dengan kebutuhan sekolah dan sesuai dengan anggaran yang tersedia. Dalam hal ini perencanaan sangat penting. Perencanaan dalam sarana dan prasarana bukan hanya masalah kuantitas dan kualitas saja, tetapi faktor-faktor edukatif lainnya juga harus diperhatikan(Andang, 2014).

SMK Negeri 1 Percut Sei Tuan merupakan sekolah unggulan Negeri favorit. Sekolah ini memiliki standar tertentu dari segi pengelolaannya dan merupakan salah satu sekolah yang mendapat predikat akreditasi A. Yang menjadi perhatian penulis adalah bagaimana proses perencanaan dalam pengelolaan sekolah yang seperti apakah yang mendukung peningkatan kualitas agar mampu memenuhi sarana dan prasarana sekolah yang bermutu sehingga menjadikan sekolah ini banyak diminati oleh masyarakat Kabupaten Deli Serdang khususnya masyarakat sekitaran kecamatan Percut Sei Tuan.

Berdasarkan pemaparan yang telah diuraikan diatas dan dengan memperhatikan berbagai fenomena-fenomena pendidikan saat ini, maka penulis berniat akan melakukan pengamatan secara menyeluruh dan mendalam terhadap pengelolaan sarana dan prasarana di SMK Negeri 1 Percut Sei Tuan. Dengan judul penelitian: PERENCANAAN SARANA DAN
PRASARANA DI SMK NEGERI 1 PERCUT SEI TUAN.

\section{Metode}

\section{Metode Dalam Penelitian}

(Moleong. Lexy J, 2006) penelitian deskriptif kualitatif ditujukan untuk mendeskripsikan dan menggambarkan fenomena-fenomena yang ada, baik bersifat alamiah maupun rekayasa manusia, yang lebih memperhatikan mengenai karakteristik, kualitas, keterkaitan antar kegiatan. (Sukmadinata. Nana Syaodih, 2007) selain itu, Penelitian deskriptif tidak memberikan perlakuan, manipulasi atau pengubahan pada variabel-variabel yang diteliti, melainkan menggambarkan suatu kondisi yang apa adanya.

(Aswita. Effi, 2012) metode pendekatan penelitian kualitatif deskriptif ini dilakukan dengan menggambarkan dan mengungkapkan manajemen sarana dan prasarana sekolah di SMK Negeri 1 Percut Sei Tuan. Peneliti akan berusaha menjelaskan secara spesifik, detail dan terperinci tentang seperti proses perencanaan sarana dan prasarana sekolah di SMK Negeri 1 Percut Sei Tuan sesuai dengan fakta dilapangan.

\section{Tempat dan Waktu Penelitian}

Lokasi penelitian tentang sarana dan prasarana pendidikan adalah di sekolah SMK Negeri 1 Percut Sei Tuan yang beralamat di Jl. Kolam No3 Kecamatan

Percut Sei Tuan Kabupaten Deli Serdang Prov. Sumatera Utara. Penelitian ini dilakukan dari bulan Mei sampai Juli. SMK Negeri 1 Percut dijadikan tempat penelitian karena peneliti menemukan fakta bahwa peningkatan kondisi sarana dan prasarana yang ada di SMK Negeri 1 Percut Sei Tuan dalam kurun waktu beberapa tahun terakhir masih belum maksimal. Kemudian tingkat keaktifan komite sekolah di SMK Negeri 1 Percut Sei Tuan dalam penyelenggaraan pendidikan khususnya pengelolaan sarana dan prsarana sekolah masih belum maksimal.

\section{Tinjauan Umum Objek Penelitian}

SMK Negeri 1 Percut Sei Tuan berdiri sejak tahun 1955. sampai sekarang, telah beberapa kali mengalami pergantian nama sekolah. Dari tahun 1955 s.d. 1964 bernama SGPT (Sekolah Guru Pendidikan Teknik) dengan Kepala Sekolahnya JM Pieter. Pada tahun 1964 s.d. 1971 bernama STM Instruktur dengan Kepala Sekolah R. Sukendar. Kemudian pada tahun 1971 s.d. 1977 bernama STM Negeri 4 Medan dan pada tahun 1997 s.d. sekarang bernama SMK Negeri 1 Percut Sei Tuan. aat ini 
SMK Negeri 1 Percut Sei Tuan berada di Jalan Kolam No. 3 Medan Estate Kecamatan Percut Sei Tuan Kabupaten Deli Serdang menempati areal seluas +/- 4 hektar dengan bangunan gedung yang permanen. Lokasi SMK Negeri 1 Percut Sei Tuan berada pada lokasi yang strategis berada di sekitar perkantoran dan perguruan tinggi besar di Kota Medan.

Pada tahun 2008 SMK Negeri 1 Percut Sei Tuan ditetapkan menjadi SMK Rintisan Sekolah Bertaraf Internasional (RSBI). SMK Negeri 1 Percut Sei Tuan juga memperoleh sertifikat "Quality Management System" ISO 9001 : 200 pada tanggal 7 Mei 2008 dan ISO 9001 : 2008 pada tanggal 18 April 2009 dari URS Jakarta. Melalui sistem manajemen mutu SMK Negeri 1 Percut Sei Tuan telah memiliki prosedur standar/ manajemen yang sesuai dengan standar nasional.

\section{Pendekatan Penelitian}

Dalam melaksanakan penelitian ini, peneliti menggunakan pendekatan kualitatif. Jenis penelitian yang digunakan oleh peneliti adalah penelitian deskriptif. Penelitian ini dimaksudkan untuk mendeskripsikan peran dan fungsi komite sekolah dalam pengelolaan sarana dan prasarana di SMK Negeri 1 Percut Sei Tuan. Metode Penelitian Kualitatif adalah metode penelitian yang berlandaskan pada filsafat postpositivisme, digunakan untuk meneliti pada kondisi obyek yang alamiah, (sebagai lawannya adalah eksperimen) dimana peneliti adalah sebagai instrument kunci, pengambilan sampel sumber data dilakukan secara purposive dan snowbaal, teknik pengumpulan dengan trianggulasi (gabungan), analisis data bersifat induktif/kualitatif, dan hasil penelitian lebih menekankan makna dari pada generalisasi. Berdasarkan pendapat di atas dapat disimpulkan bahwa, penelitian ini bermaksud untuk memahami fenomena subjek penelitian berupa perilaku, persepsi, motivasi, tindakan, dan lain sebagainya secara keseluruhan dengan metode naturalistik. Data tersebut kemudian dianalisis dan ditafsirkan agar mempunyai makna untuk diambil kesimpulan. Masalah yang ada dalam penelitian kualitatif masih bersifat sementara, sesuai dengan perjalanan penelitian masalah dapat berubah, bisa membesar bisa juga mengkrucut. Oleh karenanya judul yang diambil diawal penelitianpun bisa berubah sesuai dengan masalah yang dihadapi.

\section{Subjek Penelitian}

Dalam penelitian ini, cara pengambilan subjek penelitian adalah dengan purposive.
Suharsimi Arikunto menjelaskan bahwa dalam purposive, cara mengambil subjek penelitian bukan didasarkan atas strata, random, atau daerah tetapi didasarkan atas adanya tujuan tertentu.56 Tujuan dari penelitian ini adalah mengidentifikasi peran dan fungsi komite sekolah dalam pengelolaan sarana dan prasarana di SMK Negeri 1 Percut Sei Tuan. Dalam penelitian ini yang menjadi subjek penelitian adalah kepala sekolah, ketua komite sekolah, dewan guru, bagian sarana dan prasarana serta penjaga sekolah SMK Negeri 1 Percut Sei Tuan.

\section{Teknik Pengumpulan Data}

Teknik pengumpulan data merupakan langkah yang paling utama dalam penelitian, karena tujuan utama dari penelitian adalah mendapatkan data. Dalam penelitian ini peneliti menggunakan beberapa teknik pengumpulan data, yaitu observasi, wawancara, dan dokumentasi.

\section{Observasi}

Observasi merupakan suatu teknik atau cara mengumpulkan data dengan jalan mengadakan pengamatan terhadap kegiatan yang sedang berlangsung. Dari segi proses pelaksanaan pengumpulan data, observasi dapat dibedakan menjadi participant observation (observasi berperan serta) dan non participant observation, Dalam penelitian ini peneliti menggunakan jenis observasi nonpartisipan (non participant observation), observasi nonpartisipan adalah jenis observasi yang dalam pengamatannya pengamat tidak ikut serta dalam kegiatan, dia hanya berperan mengamati kegiatan, tidak ikut dalam kegiatan. Peneliti mengamati kinerja komite sekolah dalam pengelolaan sarana dan prasarana di SMK Negeri 1 Percut Sei Tuan tanpa harus melihat langsung kegiatan komite sekolah tersebut.

2. Wawancara

Menurut Sugiyono wawancara adalah merupakan pertemuan dua orang untuk bertukar informasi dan ide melalui Tanya jawab, sehingga dapat dikonstruksikan makna dalam suatu topik tertentu. Wawancara dalam penelitian kualitatif ini dilakukan secara terstruktur, yang mana peneliti menetapkan sendiri masalah dan pertanyaan yang akan diajukan untuk mengungkap data. Walaupun demikian, peneliti juga bisa mengembangkan pertanyaan-pertanyaan tersebut untuk memperoleh data yang lebih bermakna. Maka wawancara yang digunakan adalah wawancara bebas (terbuka). Metode wawancara ini digunakan oleh peneliti untuk menggali 
informasi terkait peran yang diberikan beserta hambatan yang ada bagi komite sekolah dalam berperan meningkatkan kualitas sarana dan prasarana yang ada di sekolah. Peneliti melakukan wawancara mendalam kepada beberapa pihak yang dirasa dapat memberikan data akurat, yaitu kepala sekolah, ketua komite sekolah, dewan guru, bagian sarana dan prasarana serta penjaga sekolah.

3. Dokumentasi

Dokumen merupakan catatan peristiwa yang sudah berlalu. Dokumen bisa berbentuk tulisan, gambar, atau karya-karya monumental dari seseorang. Studi dokumen merupakan pelengkap dari penggunaan metode observasi dan wawancara dalam penelitian kualitatif. Dokumen yang digunakan untuk memperoleh data dalam penelitian ini berupa catatan hasil rapat antara kepala

\section{Hasil dan Pembahasan Hasil Penelitian}

Sekolah memiliki prosedur pengajuan peralatan, yaitu (a) Usulan sarana prasarana dari K3, (b) Melakukan analisa kebutuhan peralatan, (c) Apabila sesuai maka usulan akan diterima, jika tidak maka kembali membuat usulan lagi, (d) Pengesahan usulan sarana prasarana. Prosedur pengadaan barang, yaitu(a) Usulan pengadaan barang dari unit kerja, (b) Pembentukan tim pengadaan, (c) Analisa usulan pengadaan barang, (d) Apabila sesuai maka diterima, jika tidak kembali membuat usulan lagi, (e) Pengesahan usulan pengadaan barang, (f) Pembelian barang, (g) Distribusikan ke kompetensi keahlian.

Prosedur perawatan dan perbaikan, yaitu (a) Koordinasi program kerja teknisi, (b) Membuat rencana penyusunan anggaran perawatan dan perbaikan, (c) Menetapkan jadwal dan jenis pekerjaan teknisi, (d) Mengusulkan anggaran perawatan dan perbaikan, (e) Melaksanakan perawatan perbaikan, (f) Melaporkan hasil pelaksanaan.

Prosedur penghapusan sarana prasarana, yaitu (a) Usulan penghapusan barang dari unit kerja, (b) Pembentukan tim penghapusan, (c) Melakukan analisa usulan penghapusan barang, (d) Apabila sesuai maka diterima, jika tidak kembali membuat usulan lagi, (e) Pengesahan usulan penghapusan barang, (f) Usulan dari Sekolah disahkan Dinas Pendidikan ke Pemerintah Daerah, (g) Usulan dari Sekolah disahkan Dinas Pendidikan Kabupaten ke Dinas Pendidikan Provinsi, (h) Usulan dari Sekolah disahkan Dinas Pendidikan Kabupaten ke Dinas Direktorat Jakarta.

\section{Prosedur sekolah dalam mengelola sarana dan prasarana sekolah}

Untuk menjawab sub masalah yang pertama maka penulis akan menjabarkan prosedur yang dilakukan dari masing- masing kompetensi keahlian, yaitu sebagai berikut: Pada Teknik Komputer dan Jaringan, perencanaan yang dibuat hanya membuat pencatatan jumlah komputer dan kondisinya, kesepakatan dan keputusan dianggap tidak perlu karena perencanaan yang dibuat sama untuk setiap tahunnya, pedoman yang diterapkan hanya mengikuti prosedur pembukuan dari sekolah, perencanaan anggaran tidak disusun karena dianggap bukan permasalahan jurusan melainkan permasalahan sekolah, prosedur hanya membuat pencatatan barang yang nantinya disampaikan kepada pihak sekolah, tidak mengikutsertakan orangtua karena dianggap sarana dan prasarana merupakan tanggung jawab wakil kepala sekolah bidang sarana dan prasarana bukan K3, pencatatan yang dilakukan sesuai dengan kondisi.

Pada Teknik Audio Video, perencanaan yang dilakukan hanya kadang-kadang karena sering terhambat antara pihak kompetensi keahlian dengan pihak sekolah, kesepakatan dan keputusan perecanaan tidak ada melibatkan pihak lain karena dianggap hanya K3 yang memiliki wewenang akan hal tersebut, perencanaan mengacu pada skala prioritas pada barang-barang yang memiliki harga mahal dan memerlukan waktu yang lama, perencanaan anggaran tidak disusun karena dianggap rencana tersebut telah dibuat oleh sekolah dan jurusan akan mendapatkan bagian dari perencanaan anggaran tersebut, kompetensi keahlian tidak mengikuti prosedur perencanaan yang ditetapkan sekolah karena beranggapan bahwa sulit untuk dipatuhi semuanya dengan alasan prosedur yang ada tidak sesuai dengan kondisi di lapangan, tidak ada mengikutsertakan unsur orangtua karena dianggap tidak ada hal yang harus dikaitkan dengan orangtua siswa mengenai sarana dan prasarana, perencanaan yang disusun memang berdasarkan keadaan karena perencanaan yang disusun tersebut kadang-kadang saja disusun, tidak ada menyusun perencanaan berdasarkan jangka waktu karena perencanaan disusunapabila membutuhkan barang yang mahal saja.

Pada Teknik Elektronika Industri, perencanaan disusun terdiri dari pencatatan barang cara penataan atau penyimpanan barang, 
Jurnal Edumaspul, 5 (2), Year 2021 - 128

(Usiono,Askur Amin,Samsir Damanik)

rencana perbaikan barang, rencana perawatan, rencana pengapusan, dan rencana pengawasan, kesepakatan dilakukan oleh semua pihak yang bertanggung jawab atas sarana dan prasarana seperti K3, guru-guru yang berkaitan dengan hal tersebut, wakil kepala sekolah bidang sarana dan prasarana, bendahara sekolah, kepala sekolah, komite sekolah, dan lain sebagainya, perencanaan disusun berdasarkan kebutuhan yang prioritas sesuai dengan jenis, jumlah, dan kualitasnya, perencanaan disusun berdasarkan dana yang di dapat oleh kompetensi keahlian dari sekolah sehingga disusun pengalokasian dana tersebut, prosedur yang digunakan semua sudah lengkap secara garis besar pada saat disusun perencanaan, tidak mengikutsertakan unsur orangtua siswa karena tidak ada perintah dari sekolah untuk mengikutsertakan unsur orangtua siswa ke dalam perencanaan sarana dan prasarana, perencanaan bersifat fleksibel dan dapat disesuaikan dengan keadaan walaupun akan berbeda dengan apa yang sudah direncanakan, perencanaan dibuat dalam waktu triwulan, semesteran, setahun, atau bahkan disusun dalam jangka waktu yang sangat lama dengan mempertimbangkan umur ekonomis dari sarana dan prasarana.

Pada Desain Permodelan dan Informasi Bangunan, perencanaan dilakukan dengan mendata barang, jumlah, kondisi barang dengan kata lain hanya melakukan inventarisasi barang, kesepakatan oleh K3, guru-guru yang berkaitan, wakil kepala sekolah bidang sarana dan prasarana, dan wakil kepala sekolah bidang hubungan industri dan masyarakat, perencanaan dilakukan hanya berdasarkan jenis barang daripada kuantitas dan kualitas karena ketersediaan barang lebih diprioritaskan, perencanaan anggaran tidak disusun karena sering terjadi ketidakseimbangan antara perencanaan dengan apa yang terjadi di lapangan, prosedur perencanaan hanya bersifat formalitas karena dianggap tetap akan berbeda apa yang direncanakan dengan apa yang akan dijalani, unsur orangtua siswa dimasukkan dalam perencanaan pengadaan dimana memprediksikan adanya bantuan dari orangtua berupa material bahan atau alat, perencanaan bersifat fleksibel dan dapat menyesuaikan dengan perubahan keadaan yang kemudian perencanaan akan ditinjau kembali untuk perencanaan kedepannya, perencanaan hanya dibuat dalam jangka waktu panjang karena dianggap rencana jangka panjang sudah mencakup rencana jangka pendek dan menengah.

\section{Implikasi prosedur sekolah dalam mengelola sarana dan prasarana sudah sesuai dengan aturan yang telah ditetapkan}

Untuk menjawab sub masalah yang kedua maka penulis akan menjelaskan dari masingmasing komponen manajemen sarana dan prasarana dengan aturan-aturan yang sesuai, sebagai berikut: Berdasarkan arsip data mengenai prosedur sarana dan prasarana menunjukkan bahwa sekolah tidak memiliki prosedur dalam melaksanakan perencanaan sarana dan prasarana sekolah. Hal ini berdampak pada kinerja komponen manajemen sarana dan prasarana sekolah yang lain karena berdasarkan teori yang telah dijabarkan pada bab sebelumnya bahwa perencanaan sarana dan prasarana merupakan komponen yang merujuk pada keseluruhan komponen manajemen sarana dan prasarana.

Kesimpulan dari hasil wawancara mengenai perencanaan sarana dan prasarana pendidikan di sekolah diperoleh informasi bahwa perencanaan yang dilakukan oleh masingmasing kompetensi keahlian dilakukan tidak sesuai, tidak beraturan, tidak jelas, dan tidak lengkap karena tidak adanya prosedur yang ditetapkan sekolah dalam menyusun perencanaan. Setiap kompetensi keahlian melakukan perencanaan yang berbeda padahal seharusnya mengacu pada pedoman yang telah ditetapkan.

Hal ini sejalan pula dengan hasil observasi yang dilakukan pada masing- masing kompetensi keahlian bahwa perencanaan yang dilakukan tidak sesuai dengan prosedur maka akan menunjukkan tata ruang yang tidak rapi dan tidak beraturan. Prosedur perencanaan sarana dan prasarana yang telah ditetapkan hendaknya dapat mencapai tujuan untuk menghindari terjadinya kesalahan pemesanan atau pembelian barang, mencegah terjadinya keterlambatan pemenuhan kebutuhan sekolah yang berdampak langsung kepada penundaan pemyampaian materi pembelajaran tertentu karena tidak tersedianya bahan praktikum. Berbeda pada penelitian sebelumnya yang menunjukkan hasil penelitian mengenai perencanaan sarana dan prasarana yang dilakukan sekolah sudah berjalan dengan baik.

Berdasarkan arsip data mengenai pengadaan sarana dan prasarana, sekolah mempunyai prosedur pengajuan peralatan yang dimana apabila pangajuan telah mendapatkan pengesahan maka akan dilakukan prosedur 
pengadaan barang. Tetapi pada kenyataannya dari hasil wawancara yang dilakukan bahwa kompetensi keahlian tidak melakukan prosedur yang telah ditetapkan dengan baik. Berdasarkan teori yang telah dijelaskan pada bab sebelumnya bahwa pengadaan sarana dan prasarana sekolah pada dasarnya merupakan upaya merealisasikan rencana pengadaan yang sudah disusun sebelumnya.

Hal ini menujukkan bahwa untuk melaksanakan pengadaan, sekolah harus membuat perencanaan terlebih. Oleh sebab itu, pengadaan sarana dan prasarana sekolah tidak berjalan sesuai dengan prosedur yang telah ditetapkan karena tidak adanya perencanaan sebelumnya. Hal ini juga sesuai dengan hasil observasi yang menunjukkan bahwa alat-alat yang tersedia sangat terbatas dalam menunjang proses iakibatkan proses pengadaan tidak dilakukan dengan baik. Berbeda pula pada hasil penelitian sebelumnya yang menunjukkan kegiatan pengadaan sarana dan prasarana sudah dilakukan dengan baik dan sesuai dengan ketentuan.

Beberapa kompetensi keahlian membuat pencatatan tetapi tidak sesuai ataupun belum lengkap karena pelaksanaan kegiatan pencatatan dan pengadministrasian barang inventaris dilakukan harus memiliki buku induk barang inventaris, buku golongan barang inventaris, buku catatan barang non- inventaris, daftar laporan triwulan, mutasi barang inventaris, dan daftar rekap barang inventaris.

Pencatatan tersebut dilakukan dengan tujuan agar menjaga dan menciptakan tertib administrasi, menghemat keuangan sekolah, pedoman menghitung kekayaan sekolah, dan memudahkan pengawasan dan pengendalian. Pencatatan yang dilakukan cenderung hanya terpaku pada berita acara dari pengadaan barang, sedangkan pada proses pengadaan barang tidak dilakukan dengan baik sehingga pencatatan tidak sesuai dengan pedoman.

Pencatatan juga tidak dilakukan proses perencanaan sehingga tampak pada hasil observasi bahwa kondisi sarana dan prasarana tidak diberi tanda ataupun kode barang yang menunjukkan adanya kegiatan pencatatan. Pada hasil wawancara juga terlihat bahwa pencatatan yang dilakukan hanya seadanya saja karena tidak adanya pedoman ataupun standar yang ditetapkan sekolah dalam melakukan inventarisasi.

Berdasarkan arsip data mengenai penyimpanan dan pemeliharaan sarana dan prasarana, sekolah mempunyai prosedur dalam melakukan perawatan dan perbaikan. Prosedur yang dimiliki sekolah sudah disusun secara sistematis dan teratur. Tetapi pada hasil wawancara menunjukkan bahwa setiap kompetensi tidak melakukan penyimpanan maupun pemeliharaan sesuai dengan prosedur yang sekolah tetapkan. Hal ini dikarenakan keterbatasan anggaran untuk dilakukan pemeliharaan ataupun merasa bahwa prosedur yang ditetapkan sekolah sangat rumit dan membutuhkan waktu yang lama. Sehingga tampak pada hasil observasi bahwa masing-masing kompetensi keahlian memiliki alat-alat yang disimpan dan tidak dapat digunakan lagi karena terhambat untuk melakukan perbaikan. Penyimpanan alat-alat yang rusak tersebut justru akan memakan tempat atau ruang penyimpanan sedangkan terlihat juga pada hasil observasi bahwa kompetensi keahlian memiliki ruang penyimpanan yang sangat terbatas.

Berdasarkan arsip data mengenai penghapusan sarana dan prasarana, sekolah mempunyai prosedur dalam melakukan penghapusan sarana dan prasarana. Pada hasil wawancara menunjukkan bahwa masing-masing kompetensi keahlian tidak melakukan kegiatan penghapusan seperti yang tertuang dalam 7 persyaratan tersebut dan sulit melakukan kegiatan penghapusan karena membutuhkan biaya yang besar dan harus adanya pergantian yang baru atas barang yang dilakukan penghapusan, sedangkan untuk pengadaan sarana dan prasarana juga sulit dilakukan karena kurangnya biaya. Hal ini juga disebabkan karena perencanaan yang tidak disusun dengan baik dari awal, kegiatan pencatatan yang tidak menunjukkan kondisi nyata dari sarana dan prasarana.

Oleh sebab itu, pada hasil observasi juga menunjukkan banyaknya alat yang seharusnya dilakukan penghapusan tetapi masih disimpan pada masing-masing kompetensi keahlian. Padahal kegiatan penghapusan sangat diperlukan untuk mengurangi pemborosan biaya pemeliharaan pada barang yang sangat rusak dan tidak dapat digunakan lagi, dapat membebaskan ruangan penyimpanan dari penumpukan barangbarang yang sudah tidak dapat digunakan lagi. pembelajaran yang Sarana dan prasarana di SMK Negeri 1 Percut Sei Tuan sudah lengkap, baik itu dari bangunan gedung sekolah, ruangan kelas, labolatorium, ruang pratikum, lapangan dan fasilitas-fasilitas lainnya. Lengkapnya sarana dan prasarana di SMK Negeri 1 Percut Sei Tuan ini tentu saja didapatkan dari pengelolaan dan 
manajemen yang baik dari pihak sekolah. Dalam hal ini, ternyata hal ini disebabkan juga karena sekolah mengadakan proses perencanaan yang baik dan persiapan yang matang. Berikut ini adalah tahapan-tahapan dalam perencanaan di SMK Negeri 1 Percut Sei Tuan, yaitu:

Menampung semua usulan pengadaan perlengkapan sekolah yang diajukan oleh setiap jurusan di SMK Negeri 1 Percut Sei Tuan

Perencanaan sarana dan prasarana di SMK Negeri 1 Percut Sei Tuan ini diawali dengan melakukan rapat perencanaan terlebih dahulu setiap akan melakukan pengadaan sarana dan prasarana pendidikannya. Rapat ini dilakukan untuk mengkoordinasikan dan mengetahui hal apa saja kebutuhan yang urgent untuk diadakan. Hasil rapat nantinya akan dianalisa, kemudian diadakan pendataan dan penentuan skala prioritas untuk disesuaikan anggaran yang dimiliki sekolah.

\section{Menyusun rencana kebutuhan perlengkapan sekolah untuk periodetertentu}

Rapat perencanaan sarana dan prasarana ini dilaksanakan setiap awal tahun anggaran, yang dihadiri oleh kepala sekolah, wakil kepala sekolah bagian sarana dan prasarana, bendahara, kepala bengkel, dan masing-masing ketua jurusan. Teknis dari perencanaan dalam rapat pengadaan sarana dan prasarana sekolah adalah dengan pengusulan kebutuhan sarana dan prasarana oleh guru-guru kepada ketua jurusan, setelah itu ketua jurusan mengajukannya dalam rapat. Dalam rapat nantinya akan diadakan pendataan/inventarisasi. Pendataan yang telah dilaksanakan akan menghasilkan daftar tentang sarana dan prasarana apa saja yang akan dilakukan pengadaan.

1. Melakukan analisis dan penentuan skala prioritas kebutuhan

Kegiatan analisa dan penentuan skala prioritas kebutuhan dilakukan setiap rapat perencanaan secara mufakat, sehingga kebutuhan yang lebih penting dan mendesak itu dilaksanakan terlebih dahulu. Pihak sekolah selalu berusaha untuk menentukan suatu tindakan atau kebijakan secara bersama melalui rapat, terbukti dengan selalu diadakan rapat dalam menganalisa sarana dan prasarana kebutuhan sekolah dan menentukan skala prioritas terhadap kebutuhan yang sangat penting dan paling diutamakan saat itu melalui berbagai pertimbangan.
2. Memadukan rencana kebutuhan dengan dana atau anggaran sekolah yang tersedia

Perencanaan kebutuhan ini kemudian disesuaikan dengan kubutuhan sekolah untuk satu tahun ke depan yang nantinya dirumuskan dalam Rencana Anggaran Pendapatan dan Belanja Sekolah (RAPBS). Sumber dana yang diperoleh dan pengalokasiaanya terperinci pada proses ini yang dirangkum dalam suatu rencana. Perencanaan sarana dan prasarana di SMK Negeri 1 Percut Sei Tuan juga melibatkan komite sekolah, biasanya akan diadakan rapat dengan komite sekolah untuk memperbincangkan kebutuhan fasilitas yang diperlukan oleh peserta didik. Ada kalanya komite sekolah juga ikut serta dalam pengadaan sarana dan prasarana di SMK Negeri 1 Percut Sei Tuan.

\section{Pembahasan}

\section{Perencanaan Sarana Dan Prasarana}

Perencanaan adalah sebuah proses perdana ketika hendak melakukan pekerjaan baik dalam bentuk pemikiran maupun kerangka kerja agar tujuan yang hendak dicapai mendapatkan hasil yang optimal. Salah satu alasan utama menempatkan perencanaan sebagai fungsi organik manajerial yang pertama ialah karena perencanaan merupakan langkah konkret yang pertamakali diambil dalam usaha pencapaian tujuan. Artinya, perencanaan merupakan usaha konkretisasi langkah-langkah yang harus ditempuh yang dasar-dasarnya telah diletakkan dalam strategi organisasi (Rusydi Ananda, Oda Kinata Banurea, 2017).

Perencanaan ialah sejumlah kegiatan yanga kandilakukan dimasa yang akan datang untuk mencapai tujuan. Dari definisi ini perencanaan mengandung unsur-unsur (1) sejumlah kegiatan yang ditetapkan sebelumnya, (2)adanya proses, (3)hasil yang ingin dicapai, dan(4) menyangkut masa depan dalam waktu tertentu.

Fungsi perencanaan adalah sebagai pedoman pelaksanaan dan pengendalian, menentukan strategi pelaksanaan kegiatan, menentukan tujuan atau kerangka tindakan untuk mencapai tujuan tertentu. Dalam menentukan rencana harus dilakukan secara matang dengan melakukan kajian secara sistematis sesuai dengan kondisi organisasi dan kemampuan sumber daya dengan tetap mengacu pada visi dan misi organisasi (Sondang Siagian P, 2007).

Defenisi sederhana diatas sesungguhnya mengandung ematpokok pikiran sebagai berikut: Pertama: Suatu rencana tidak akan 
timbul dengan sendirinya melaink dan lahirse bagai hasil pemikiran yang bersumber pada hasil penelitian yang telah dilakukan. Kedua, Paramanager selaku perencana mutlak perlu memiliki keberanian mengambil keputusan dengan segala resiko. Ketiga, Orientasi suatu rencana ialah masa depan. Keempat, Rencana harus mempunyai makna bahwa apabila rencana itu dilaksanakan, ia akan mempermudah usaha yang akan dilakkan dalam pencapaian tujan organisasi yang bersang kutan (Hadi Sutrisno, 2001).

(Usman, 2006) berikut ini merupakan ciri-ciri rencana yang baik,s ebagai berikut:

1. Rencana harus mempermudah tercapainya tujuan yang telah ditetapkan sebelumnya.

2. Perencana sungguh-sungguh memahami hakikat tujuan yang ingin dicapai.

3. Rencana memenuhi persyaratan keahlian tekhnis.

4. Rencana harus disertai suatu rincian yag cermat.

5. Rencana berkaitan dengan pelaksanaan manajemen.

6. Rencana disusun dengan bahasa yang sederhana, jelas, sistematik, formal dan menggunakan format dan penekanan prioritas yang baik.

7. Rencana bersifat fleksibilitas, (Sondang Siagian P, 2007).

Al-Qur'an menyatakan dalamQ. S. Al-

Hasyr ayat 18 beberapa konsep mengenai

perencanaany aitu:

"Hai orang-orang yang beriman, bertaqwalah kepada Allah dan hendaklah setiap diri memperhatikan apa yang telah diperbuatnya untuk hari esok (akhirat) dan bertaqwalah kepada Allah, sesungguhnya Allah Maha Mengetahui apa yang kamu kerjakan."

Perencanaan yang baik akan dicapai dengan mempertimbangkan kondisi diwaktu yang akan datang dalam mana perencanaan dan kegiatan yang akan diputuskan akan dilaksanakan, serta periode sekarang pada saat rencana di buat. Ketika menyusun sebuah perencanaan dalam pendidikan Islam tidaklah dilakukan hanya untuk mencapai tujuan dunia semata, tapi harus jauh lebih dari itu melampaui batas-batas target kehidupan duniawi. Arahkanlah perencanaan itu juga untuk mencapai target kebahagiaan dunia dan akhirat, sehingga kedua-duanya bisa dicapai secara seimbang.

Adapun sarana dan prasarana pendidikan terdiri dari dua unsur, yaitu sarana dan prasarana. Sarana pendidikan adalah peralatan dan perlengkapan yang secara langsung dipergunakan dan menunjang proses pendidikan, khususnya proses belajar mengajar, seperti gedung, ruangkelas, mejakursi, sertaalat-alat dan media pengajaran. Adapun yang dimaksud dengan prasarana pendidikan adalah fasilitas yang secara tidak langsung menunjang jalannya suatu proses pendidikan atau pengajaran, seperti halaman, kebun, taman sekolah, jalan menuju sekolah, tetapi jika dimanfaatkan secara langsung untuk proses belajar mengajar,s eperti taman sekolah Islam untuk pangajaran biologi, halaman sekolah Islam sebagai lapangan olah raga, komponen tersebut merupakan saranapendidikan. (Rahmat Hidayat, Candra Wijaya, 2017).

Dalam Alquran juga ditemukan ayatayat yang menunjukkan bahwa pentingnya sarana dan prasarana atau alat dalam pendidikan. Alquran menjelaskan bahwa alam raya yang diciptakan Allah Swt. Dapat dijadikan sarana untuk belajar, seperti hewan misalnya bisa menjadi alat dalam pendidikan. Sebagaimana dijelaskan dalam salah satu surat dalam Alquran yaitu Surat an-Nahl/16 yang artinya lebah ayat ke 68 dan 69 yang artinya:

Artinya: Dan Tuhanmu mewahyukan kepada lebah: "Buatlah sarang- sarang di bukit-bukit, di pohon-pohon kayu, dan di tempat-tempat yang dibikin manusia",kemudian makanlah dari tiaptiap (macam) buah-buahan dantempuhlah jalan Tuhanmu yang telah dimudahkan (bagimu). Dari perut lebah itu ke luar minuman (madu) yang bermacam-macam warnanya, di dalamnya terdapat obat yang menyembuhkan bagi manusia. Sesungguhnya pada yang demikian itu benar-benar terdapat tanda (kebesaran Tuhan) bagi orang-orang yang memikirkan.

Ayat di atas menerangkan bahwa lebah bisa menjadi media atau alat bagi orang-orang yang berpikir untuk mengenal kebesaran Allah yang pada gilirannya akan meningkatkan keimanan dan kedekatan (taqarub) seorang hamba kepada Allah Swt. Nabi Muhammad saw. Dalam mendidik para sahabatnya juga selalu menggunakan alat ata umedia, baik berupa benda maupun non-benda. Salahsatu alat yang digunakan Rasulullah dalam memberikan pemahaman kepada parasahabatnya adalah dengan menggunakan gambar.

Jadi padadasarnya perencanaan sarana dan prasarana merinci rancangan pembelian, 
pengadaan, rehabilitasi, distribusi atau pembuatan peralatan dan perlengkapan sesuai dengan kebutuhan fasilitas sekolah. Dengan demikian perencanaan sarana dan prasarana persekolahan dapat didefinisikan sebagai keseluruhan proses perkiraan secara matang rancangan pembelian, pengadaan rehabilitasi, distribusi atau pembuatan peralatandan perlengkapan yang sesuai dengan kebutuhan sekolah.

\section{Simpulan}

Perencanaan sarana dan prasarana di SMK Negeri 1 Percut Sei Tuan merupakan tahapan awal dalam pengelolaan sarana dan prasarana di sekolah tersebut, di dalam perencanaan itu ada keseluruhan proses perkiraan secara matang rancangan kebutuhan fasilitas yang diperlukan oleh peserta didik, guru-guru dan seluruh staf yang ada di SMK Negeri 1 Percut Sei Tuan, termasuk rancangan pembelian, pengadaan rehabilitasi, distribusi serta pengadaan perlengkapan sekolah tersebut. Perencanaan sarana dan prasarana pendidikan di SMK Negeri 1 Percut Sei Tuan dilakukan melalui tahapan sebagai berikut:

a. Menampung semua usulan pengadaan perlengkapan sekolah yang diajukan oleh setiap jurusan diSMK Negeri 1 Percut Sei Tuan.

b. Menyusun rencana kebutuhan perlengkapan sekolah untuk periode tertentu.

c. Melakukan analisis dan penentuan skala prioritas kebutuhan.

d. Memadukan rencana kebutuhan dengan dana atau anggaran sekolah yangt ersedia.

e. Penetapan rencana pengadaan sarana dan prasarana.

\section{Daftar Pustaka}

Aswita. Effi. (2012). Metodologi Penelitian Pendidikan, Medan: Unimed Press.

Andang.(2014).ManajemendanKepemimpinanKe palaSekolah:Konsep,Strategi,danInovasiMe nujuSekolahEfektif.Yogyakarta:ARRUZZMEDIA.
Ananda.RusydidanBanurea.OdaKinata.(2017).M anajemenSaranadanPrasaranaPendidikan, Medan: Widya Puspita.

DirektoratTenagaKependidikan.(2007).Manajem ensaranadanPrasaranaPendidikanPersekol ahanBerbasisSekolah.Jakarta.

Hadi. Sutrisno. (2001). Metodologi Research Jilid II, Yogyakarta: Andi Offset.

H. Usman. (2006). Manajemen: teori, praktik dan riset pendidikan. Jakarta: BumiAksara.

Hidayat.RahmatdanWijaya.Candra.(2017).AyatayatAl-

Qur'antentangManajemenPendidikanIslam. Medan: LPPPI.

Moleong.LexyJ.(2006),MetodologiPenelitianKuali tatif.Bandung:PTRemajaRosdakarya.

Minarti.Sri.(2016).ManajemenSekolah(Mengelola LembagaPendidikanSecaraMandiri).Yogya karta: Ar-Ruzz Media.

Siagian. Sondang P. (2007). Fungsi-Fungsi Manajerial. Jakarta: Bumi Aksara.

Sukmadinata.NanaSyaodih,(2007),MetodePenelit ianPendidikan.Bandung:RemajaRosdakary a.

Tim Pakar Manajemen Pendidikan Universitas Negeri Malang. (2003). Manajemen Pendidikan.Malang: Universitas Negeri Malang.

Zaini, Muhammad Fuad, and Syafaruddin Syafaruddin. 2020. "The Leadership Behavior of Madrasah Principals in Improving the Quality of Education in MAN 3 Medan." Jurnal Iqra': Kajian Ilmu Pendidikan 5(2): 95-106. https://journal.iaimnumetrolampung.ac.id /index.php/ji/article/view/649.

\section{Profil Penulis}

Usiono, Saat ini berprofesi sebagai Dosen di Fakultas Tarbiyah dan Ilmu keguruan Universitas Islam Negeri Sumatera Utara Medan.

Askur Amin, lahir di Haloban pada tanggal 08 November 1986, saat ini sedang melanjutkan studi di Universitas Islam Negeri Sumatera Utara Medan dan berprofesi sebagai guru.

Samsir Damanik, lahir di Bandar Minggu pada tanggal 06 April 1987, saat ini sedang melanjutkan studi di Universitas Islam Negeri Sumatera Utara Medan. 